\title{
0 gênero Galeandra (Orchidaceae) na Amazônia Brasileira
}

\author{
Silvana Helena N. MONTEIRO ${ }^{1 *}$, Manoela Ferreira Fernandes da SILVA², Ricardo de Souza SECCO ${ }^{2}$
}

RESUMO

Este trabalho consiste no estudo florístico e taxonômico das espécies do gênero Galeandra Lindl. na Amazônia Brasileira. Foi confirmada a ocorrência de sete espécies: G. baueri Lindl., G. curvifolia Barb. Rodr., G. devoniana Schomb. ex Lindl., G. lacustris Barb. Rodr., G. montana Barb. Rodr., G. stangeana Rchb.f. e G. stillomisantha (Vell.) Hoenhe. Galeandra. baueri foi considerada nova ocorrência para a flora do Brasil. Apesar de G. beyrichii Rchb.f. e G. paraguayensis Cogn. não ocorrerem em áreas da Amazônia Brasileira propriamente dita, elas foram incluídas neste estudo porque ocorrem em áreas pertencentes à Amazônia Legal. São apresentadas chave de identificação, descrições e ilustrações, bem como comentários sobre a distribuição geográfica, hábitat e aspectos fenológicos para as espécies estudadas.

PALAVRAS-CHAVE: Galeandra, Orchidaceae, Taxonomia.

\section{The genus Galeandra (Orchidaceae) in the Brazilian Amazon}

\section{ABSTRACT}

This paper is an inventory of species of the genus Galeandra Lindl. in the Brazilian Amazon. The occurrence of seven species was confirmed: G. baueri Lindl., G. cu bw rvifolia Barb. Rodr., G. devoniana Schomb. ex Lindl., G. lacustris Barb. Rodr., G. montana Barb. Rodr., G. stangeana Rchb.f. and G. stillomisantha (Vell.). Galeandra baueri was considered a new record for the flora of Brazil. Although G. beyrichii Rchb.f and G. paraguayensis Cogn. do not occur in the Brazilian Amazon, they were included in the paper because they occur in areas belonging to the Legal Amazon. Identification key, descriptions and illustrations are presented, as well as comments on the geographical distribution, habitat and aspects of phenology for the studied species.

KEYWORDS: Galeandra, Orchidaceae, Taxonomy.

\footnotetext{
1 Programa de Pós-Graduação em Agronomia, Área de Concentração: Biologia Vegetal Tropical. Universidade Federal Rural da Amazônia, Avenida Presidente Tancredo Neves, 2501 CEP 66.077-530, Caixa Postal: 917- Belém - PA - Brasil.

${ }^{2}$ Museu Paraense Emílio Goeldi, Coordenação de Botânica - CBO, Av. Perimetral, 1901, CEP 66077-830 - Belém - PA - Brasil

* Autor para correspondência (silvana.helenamonteiro@gmail.com)
} 


\section{INTRODUÇÃO}

A família Orchidaceae é considerada por alguns autores como a maior família das fanerógamas (Garay, 1960; Willis, 1973; Bechtel et al., 1986). Tem entre 17.000 a 35.000 espécies, distribuídas em cerca de 700 gêneros e seus representantes habitam praticamente todas as regióes e climas do planeta, sendo que a maioria ocorre nos trópicos, predominando as de hábito epifítico (Dressler, 1993).

O Brasil apresenta uma privilegiada flora orquidológica e, segundo Barros (1996), o país tem aproximadamente 2400 espécies, porém essa cifra é constantemente alterada devido às novas descobertas em locais pouco ou não estudados. $\mathrm{A}$ grande extensão territorial do Brasil, a riqueza de espécies e a carência de especialistas neste grupo, contribuem para a falta de dados sobre a taxonomia, ecologia e distribuição geográfica dos numerosos táxons desta família. Assim, é grande a escassez de pesquisas sobre gêneros de Orchidaceae com valor horticultural como, por exemplo, o gênero Galeandra que, apesar de possuir flores com potencial ornamental, tem recebido pouca atenção por parte dos taxonomistas, sendo a sua última revisão apresentada por Cogniaux (1895), na Flora Brasiliensis.

Galeandra é um gênero neotropical, membro da subtribo Cyrtopodiinae, possuindo cerca de 30 espécies, distribuídas desde o sul da Flórida e México, atravessando a América Central, Índias Ocidentais e a América do Sul até o Paraguai. A maioria das espécies é encontrada no Brasil, considerado o seu centro de diversidade, vinte e dois táxons são descritos para o país, sendo que 16 são citados para a Amazônia Brasileira. O Gênero foi proposto por Lindley (1832), tendo por base uma planta coletada em Caiena, na Guiana Francesa. O epíteto genérico foi dado em alusão à forma da antera que lembra mais ou menos o formato de um capacete, sendo composto por duas palavras, galea e andro, que significam respectivamente capacete e macho.

As espécies do gênero ou são ervas epífitas, com pseudobulbos cilíndricos ou fusiformes, ou ervas terrestres, com pseudobulbos ovóides, curtos e engrossados. As folhas são simples e alternas, variando de estreitamente lineares a oblongo-lanceoladas. A inflorescência é terminal, em racemo ou panícula. As flores geralmente são grandes, raras vezes pequenas. O labelo é infundibuliforme com calcar; nas epífitas o calcar é alongado, delgado com ápice atenuado, enquanto nas terrestres ele é curto, obtuso ou filiforme. O fruto é uma cápsula oblonga, tricarpelar, deiscente, seca e com numerosas e diminutas sementes. As características mais marcantes para distinção entre as espécies são a presença ou ausência de indumento na superfície do labelo e da coluna, o número de carenas e o formato do labelo quando distendido.

Apesar da diversidade de Galeandra na Amazônia brasileira, são raros os estudos sobre o gênero na região, o trabalho mais significativo é o da "Flora Brasiliensis", que inclui 11 espécies. Algumas dessas espécies são conhecidas apenas pelo material-tipo e muitas vezes as descriçôes originais apresentam-se de forma resumida, utilizando caracteres diagnósticos inconsistentes. $\mathrm{O}$ pouco conhecimento sobre o gênero, além da falta de uma chave taxonômica, dificulta o reconhecimento das espécies, comumente há material sem identificação depositado nos herbários brasileiros e confusão na nomeação das espécies. Desta forma, este trabalho teve como objetivo realizar o estudo florístico e taxonômico das espécies de Galeandra que ocorrem na Amazônia brasileira, fornecendo chave de identificação, descriçōes, ilustraçōes e dados sobre época de floração e distribuição geográfica para as espécies da região.

\section{MATERIAL E MÉTODOS}

O material utilizado no estudo foi proveniente de coletas feitas através do projeto "Estudo e Conservação de Orquídeas da Amazônia Brasileira DBO-MPEG", bem como amostras herborizadas procedentes de diversas instituiçōes nacionais: BHCB, CEN, HB, IAN, INPA, MG, R, RB, SP, UB (siglas de acordo com Holmgren et al., 1990).

A identificação do material foi feita com base nos trabalhos de Cogniaux (1895) e Pabst \& Dungs $(1975,1977)$ e através das diagnoses originais. As descrições do gênero e das espécies foram baseadas no material coletado e nas exsicatas provenientes dos herbários consultados. Para a descrição das estruturas dos táxons foi utilizada a nomenclatura proposta nos trabalhos de Radford et al. (1974) e Sheehan \& Sheehan (1994).

As informações sobre a coloração das flores e frutos, hábitat, hábito, floração e distribuição geográfica foram baseadas nas observações de coleções vivas e nas informaçôes das etiquetas das exsicatas. A abreviação dos autores dos nomes científicos foi baseada em Brummit \& Powell (1992).

A citação do material examinado está na seqüência de estado, município ou localidade, data, coletor e número de coleta e sigla de herbário. No caso de falta do número do coletor, foi adicionado, após a sigla, o número de registro do herbário.

As sinonímias apresentadas foram compiladas a partir de Cogniaux (1895), Foldats (1970), Pabst \& Dungs (1975, 1977) e Sprunger et al. (1996).

\section{RESULTADOS E DISCUSSÃO}

A Tabela 1 mostra que das 16 espécies citadas para a Amazônia Brasileira, apenas sete foram encontradas nas coleçôes de herbário consultadas ou foram coletadas para este estudo. A grande plasticidade fenotípica das espécies e a pouca representatividade das plantas nas coleçôes de herbário, que 
muitas vezes continham pouquíssimos indivíduos ou nem tinha representantes nas coleçôes, dificulta a delimitação dos táxons e, freqüentemente, provocam confusão tanto em literatura, como em material de herbário, por isso e provável que as espécies que não foram encontradas sejam apenas sinônimos dos táxons aceitos neste estudo. Mas para tal afirmação, é necessário o exame de coleções históricas, principalmente as dos herbários estrangeiros, onde está depositado o material-tipo dessas espécies, além da ampliação das áreas de coleta para que se possa avaliar adequadamente a delimitação dos táxons faltantes.

Apesar de não ocorrerem na Amazônia propriamente dita G. beyrichii Rchb.f. e G. paraguayensis Cogn. foram incluídas no trabalho pois são localizadas em áreas consideradas da Amazônia Legal. A seguir apresenta-se a descrição do gênero e das espécies consideradas.

Tabela 1 - Táxons citados para a Amazônia Brasileira. Espécies sublinhadas foram citadas para a região, porém, neste estudo não foram recoletadas ou encontradas nas coleções examinadas.

\begin{tabular}{ll}
\hline Espécie & Obra \\
\hline Galeandra barbata Lem. & III. Hort. iii. Misc. 86, 89. 1856 \\
\hline Galeandra baueri Lindl. & III. Orch. Pl. tab. 8. 1832. \\
\hline Galeandra camptoceras Schltr. & Repert. Spec. Nov. Regni Veg. \\
Galeandra claesii Cogn. & 8: 454. 1910 \\
\hline Galeandra cristata Lindl. & Lindenia 9: 17, pl. 391. 1893 \\
Galeandra curvifolia Barb.Rodr. & Bot. Reg. 72.1844. \\
Galeandra devoniana Schomb. ex Lindl. & Gen. Sp. Orchid. 1: 85. 1877. \\
Galeandra dives Rchb.f. \& Warsz. & Bonplandia. 2: 98. 1840 1854. \\
Galeandra harveyana Rchb.f. & Gard. Chron. II: 716. 1883. \\
Galeandra huebneri Schltr. & Beih. Bot. Centralbl. 42, pt. 2: \\
Galeandra lacustris Barb.Rodr. & 111. 1925 \\
\hline Galeandra minax Rchb.f. & Gen. Sp. Orchid. 1: 86. 1877. \\
Galeandra montana Barb.Rodr. & Gard. Chron. I: 786. 1874. \\
Galeandra nivalis Mast. & Revista Engen. 3(5): 73. 1881. \\
Galeandra stangeana Rchb.f. & Gard. Chron. I: 537. 1882. \\
Galeandra styllomisantha (Vell.) Hoehne & Bonplandia, 4. 323. 1856. \\
\hline
\end{tabular}

\section{DESCRIÇÃO DO GÊNERO}

Galeandra Lindl., Illustr. Orch. Pl. Gen. t. 8. 1832. Corydandra Rchb. Deut. Bot. Herb.-Buch 53. 1841.

Ervas epífitas ou terrestres. Pseudobulbos curtos $(2-6$ $\mathrm{cm}$ de compr.) ovóides, revestidos por finas escamas ou fusiformes (10 - $80 \mathrm{~cm}$ de compr.), cilíndricos, estreitandose para o ápice, pouco atenuados na base, algumas vezes dorsiventralmente comprimidos, revestidos por bainhas escariosas pintalgadas, invaginantes, imbricadas. Folhas dísticas, cartáceas, estreitamente lineares a oblongo-lanceoladas, acuminadas, ligeiramente arqueadas. Inflorescências em racemo ou panícula, pauci ou plurifloras, eretas ou subpêndulas, pedúnculo recoberto por uma ou mais brácteas escariosas, imbricadas, lineares, com ápice longamente acuminado e base invaginante, raque com uma bráctea na base. Ovário pedicelado ereto ou ligeiramente flexuoso, pubérulo, sulcado no ápice, com uma bráctea esverdeada na base, algumas vezes com tons avermelhados nas nervuras, escariosa na antese, triangular-lanceolada, com ápice acuminado. Flores geralmente grandes, raras vezes pequenas. Sépalas livres, membranáceas, agudas ou ligeiramente apiculadas, inferiormente pouco atenuadas, margens inteiras, levemente revolutas, pubérulas, sépala dorsal oblongo-lanceoladas, algo encurvada ou eretopatente; sépalas laterais ligeiramente falcadas, principalmente na face abaxial. Pétalas semelhantes à sépala dorsal, porém um pouco mais largas. Labelo membranáceo, infundibuliforme (em posição natural), suborbicular a rombóide (quando distendido), trilobado; disco composto por $2-4$ carenas paralelas, carenas internas delgadas e alongadas, as externas curtas, espessas em direção ao ápice ou à base; algumas vezes 2 ou 3 nervuras paralelas e mais espessadas que passam por entre as carenas, com aspecto de outras carenas, essas nervuras iniciam-se no calcar e prolongam-se até o ápice do labelo, a parte interna da lâmina com indumento pubérulo, principalmente no centro e nos lobos; calcar retuso com ápice agudo ou cônico com ápice obtuso ou filiforme com ápice atenuado, internamente pubérulo a pubescente, reto a ascendente. Coluna semicilíndrica, apiculada, com formato aproximadamente triangular (em corte transversal), ligeiramente encurvada, glabra, esparsamente pubérula ou vilosa, cavidade estigmática com alas laterais, base com pequenas aurículas laterais, avermelhadas ou não. Antera subarredondada, prolongando-se em uma crista carnosa, ápice obtuso, violáceo, base com uma protuberância no dorso com tricomas diminutos. Polinário com viscídio interno, central; estipe transparente, laminar lembrando um "T" invertido ou espesso lembrando um "V" invertido, polínias duas, sólidas, amarelas, ovóides, livres ou justapostas pelo caudículo. Fruto cápsula, oblongo, tricarpelar, deiscente, seco, sementes numerosas.

\section{Espécie-tipo: Galeandra baueri Lindl.}

Etimologia: John Lindley (1832) escolheu o epíteto genérico aparentemente em alusão à forma da antera que lembra mais ou menos o formato de um capacete. O nome do gênero é composto por duas palavras, galea e andro, que significam respectivamente capacete e macho (Senghas, 1991).

O gênero Galeandra Lindl. pertence à subfamília Epidendroideae, por apresentar folhas distícas, caducas, polínias sólidas e antera caduca. Pertence à tribo Cymbidieae por ter folhas plicadas e duas polínias e à subtribo Cyrtopodiinae 
por apresentar folhas dísticas, articuladas, flores ressupinadas, labelo com calcar, polinário com duas polínias, estipe e viscídio.

\section{CHAVE PARA IDENTIFICAÇÃO DAS ESPÉCIES DE GALEANDRA OCORRENTES NA AMAZÔNIA BRASILEIRA}

1. Plantas epífitas, pseudobulbos alongados $(10-80 \mathrm{~cm}$ de compr.), delgados, cilíndricos ou fusiformes

2. Coluna conspicuamente vilosa.

3. Pilosidade lanosa no ápice das carenas .... G. stangeana

3'. Pilosidade lanosa ausente no ápice das carenas ... G. lacustris

2'. Coluna glabra ou esparsamente pubescente.

4. Flores perfumadas, calcar curvado para baixo e internamente glabro ou esparsamente pubescente, carenas espessas em direção ao ápice do disco ...... $G$. devoniana

4'. Flores sem perfume, calcar reto e internamente pubescente, carenas espessas em direção à base do disco

5. Inflorescência com $1-3$ flores, labelo com listras lilases a vináceas e numerosas pontuações vináceas, base do labelo estreita, carenas externas próximas entre si................... G. curvifolia

5'. Inflorescência com 4-16 flores, labelo sem listras e pontuações, base do labelo alargada, carenas externas afastadas entre si.....G. baueri

1'. Plantas terrestres, pseudobulbos curtos $(2-6 \mathrm{~cm}$ de compr.), engrossados, ovóides.

\section{Calcar filiforme.}

7. Flores com labelo lilás claro, com pequenas listras vináceas no lobo mediano, ápice obtuso, emarginado; sépalas e pétalas da mesma cor do labelo........... G. styllomisantha

7'. Flores com labelo branco com tons róseos, sem listras vináceas nas margens do lobo mediano, ápice longamente acuminado, sépalas e pétalas com coloração diferente do labelo G. paraguayensis

6'. Calcar obtuso.

8. Plantas áfilas durante a floração, inflorescência racemosa, (6 - 16 flores), labelo incospicuamente trilobado ........................ beyrichii

8'.Plantas com folhas durante afloração, inflorescência paniculada ( $2-3$ flores), labelo conspicuamente trilobado...

G. montana
1. Galeandra stangeana Rchb.f., Bonplandia 4: 323 . 1856.

Galeandra villosa Barb. Rodr., Gen. Sp. Orchid. 1: 85. 1877.

\section{FIGURA 1.}

Epífita. Pseudobulbos fusiformes, $15-18 \mathrm{~cm}$ compr., ca. $0,79 \mathrm{~cm}$ diâm. Folhas lineares, $6,7-20,5 \mathrm{~cm}$ compr., 6-10 mm larg. Inflorescência paniculada, 1 - 8 flora, ca. 6 cm compr., subpendula, pedúnculo verde-pardacento, 5- 10 $\mathrm{cm}$ de comprimento, recoberto por poucas brácteas; brácteas do pedúnculo $11-13 \mathrm{~mm}$ compr.; raque de tom mais claro que o pedúnculo, $1,2-6 \mathrm{~cm}$ compr. Ovário pedicelado verde-claro, ca. $2 \mathrm{~cm}$ compr., bráctea floral $5-6 \mathrm{~mm}$ de compr. Flores de tamanho médio. Sépalas esverdeadas com estrias castanho-avermelhadas; sépala dorsal algo encurvada, $20-22 \mathrm{~mm}$ compr., ca. $4 \mathrm{~mm}$ larg.; sépalas laterais $22-23$ $\mathrm{mm}$ de compr., ca. $5 \mathrm{~mm}$ larg. Pétalas $17-18 \mathrm{~mm}$ compr., ca. $4 \mathrm{~mm}$ larg. Labelo rômbico-obovado, $45-50 \mathrm{~mm}$ compr., $27-29 \mathrm{~mm}$ larg., lilás-purpúreo com listras de tons mais claros que vão do calcar até a região mediana, ápice levemente retuso, margem ligeiramente crenulada; disco composto por 4 carenas amareladas ou branco-rosadas, espessas no ápice, com indumentos lanosos que se estendem até o ápice do lobo mediano; calcar filiforme, com ápice atenuado, ligeiramente ascendente, amarelo-esverdeado com algumas listras vináceosacastanhadas, internamente pubescente. Coluna com a superfície ventral vilosa, branco-rosada, ca. $10 \mathrm{~mm}$ compr., ca. $25 \mathrm{~mm}$ larg. Antera branca. Polinário com estipe espesso, formato de "V" invertido.

Distribuição geográfica: $G$. stangeana ocorre na Venezuela, Colômbia, Peru e Brasil. No Brasil é encontrada nos estados do Amazonas, Mato Grosso e Pará.

Florescimento: Floresce de abril a junho.

Material examinado: Brasil: Amazonas: Margem direita do rio Negro, perto do lago Salvador, $20 \mathrm{~km}$ de Manaus, 13/V/1972, Pabst 9419 (HB). Pará: Santarém, Lago Verde, Alter do Chão, VI/1999, Silva 814 (MG). Mato Grosso: Município de Alta Floresta, s/d., Silva 809 (MG).

Distingue-se das demais espécies do grupo pela vilosidade da superfície ventral da coluna e a forma de arco do estipe e das aurículas ao lado da cavidade estigmática e pela concentração de indumento lanoso em frente às carenas. 


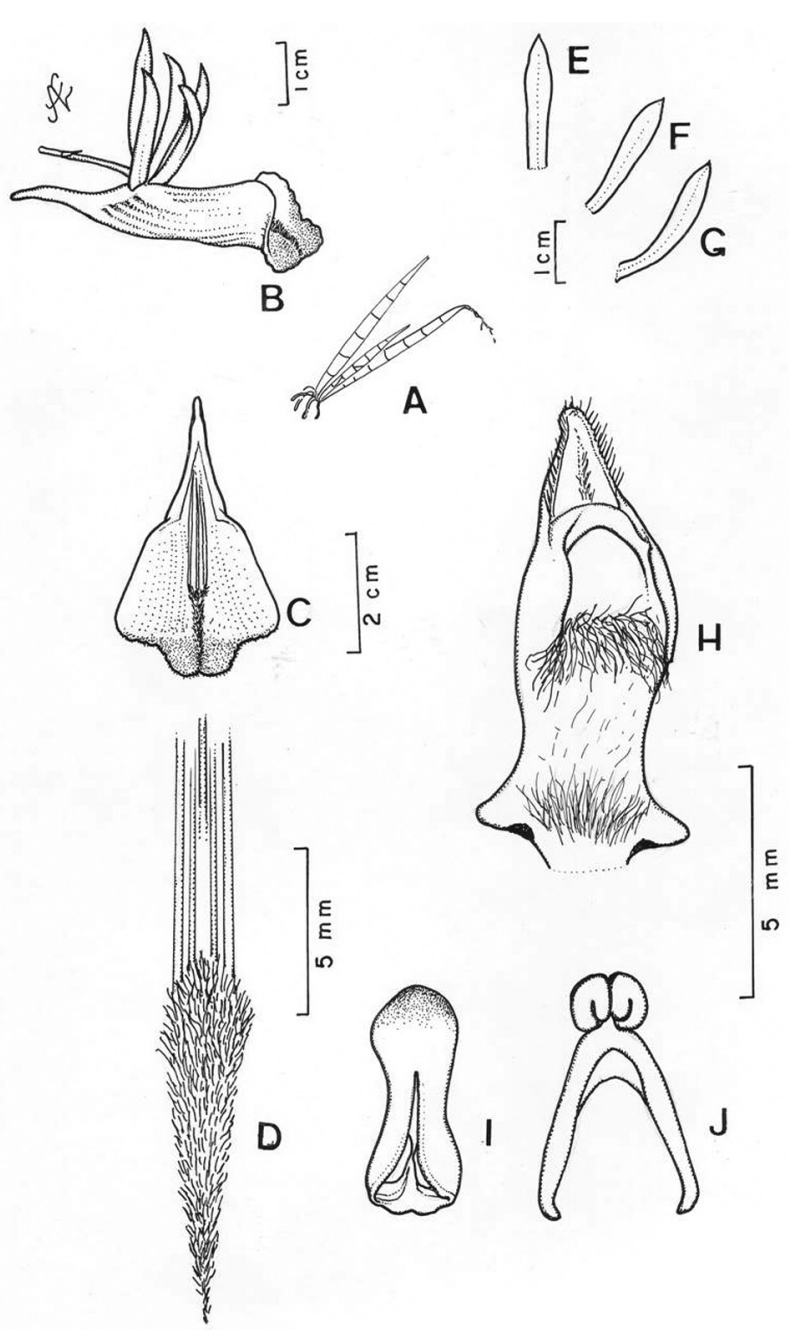

Figura 1 - Galeandra stangeana. A hábito. B flor inteira. C labelo (lâmina aberta). $\mathbf{D}$ detalhe do ápice das carenas. $\mathbf{E}$ sépala dorsal. $\mathbf{F}$ pétala. $\mathbf{G}$ sépala lateral. H coluna. I antera (vista frontal). J polinário.

\section{Galeandra lacustris Barb. Rodr., Gen. Sp. Orchid.}

\section{1: 86. 1877.}

Galeandra d'escagnolleana Rchb.f., Ill. Hort. 34: 63. t. 22. 1887.

\section{FIGURA 2.}

Epífita. Pseudobulbos fusiformes, $0,51-0,80 \mathrm{~cm}$ diâm. Folhas lineares-lanceoladas, $4,7-12 \mathrm{~cm}$ compr., $6-11 \mathrm{~mm}$ larg. Inflorescência paniculada, 1-2 flora, ca. 8,1 cm compr., subpendula; pedúnculo verde-claro a verde-pardacento, ca. 6,9 cm compr., recoberto por várias brácteas; brácteas do pedúnculo $11-44 \mathrm{~mm}$ compr.; raque verde-pardacenta, $1,2 \mathrm{~cm}$ compr. Ovário pedicelado verde-claro, ca. $21 \mathrm{~mm}$ compr., bráctea floral ca. $4 \mathrm{~mm}$ compr. Flores de tamanho medio. Sépalas castanho-avermelhadas com tons esverdeados; sépala dorsal ereto-patente, ca. $16 \mathrm{~mm}$ compr., ca. $3 \mathrm{~mm}$ larg.;

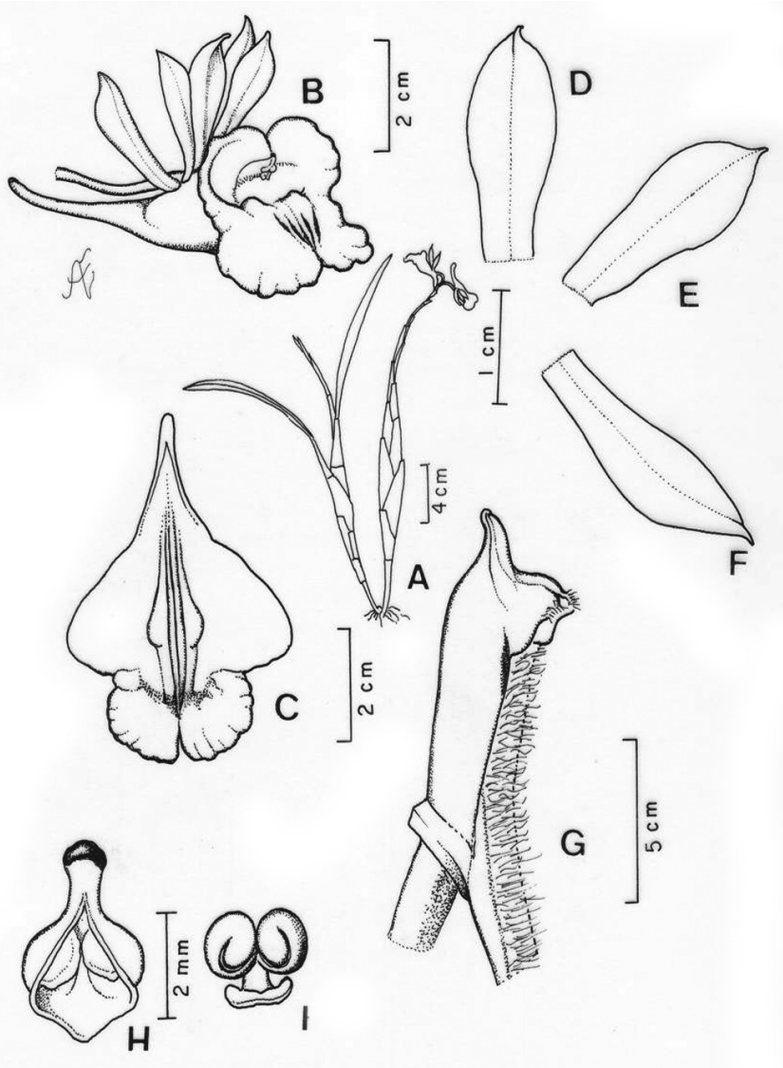

Figura 2 - Galeandra lacustris. A hábito. B flor inteira. C labelo (lâmina aberta). D sépala dorsal. E pétala. $\mathbf{F}$ sépala lateral. $\mathbf{G}$ coluna. $\mathbf{H}$ antera (vista frontal). I polinário.

sépalas laterais ca. $18 \mathrm{~mm}$ compr., ca. $4 \mathrm{~mm}$ larg. Pétalas ca. $17 \mathrm{~mm}$ compr., $5 \mathrm{~mm}$ larg. Labelo rômbico-obovado, ca. 48 $\mathrm{mm}$ compr., ca. $35 \mathrm{~mm}$ larg., branco ou branco- amarelado, com mancha violácea em forma de "V" no lobo mediano, ápice emarginado, margem do lobo mediano ligeiramente ondulada e margem dos lobos laterais lisa; disco composto por 4 carenas esbranquiçadas, pubérulas, as externas espessas no ápice, lembrando uma meia-lua; calcar filiforme, com ápice atenuado, amarelo-ouro, horizontal ou ligeiramente ascendente, internamente glabro ou com indumento pubérulo esparso. Coluna com a superfície ventral vilosa, brancoesverdeada, $10 \mathrm{~mm}$ compr., $3 \mathrm{~mm}$ larg. Antera amarelada. Polinário com estipe laminar, formato de " $T$ " invertido.

Distribuição geográfica: ocorre na Venezuela, Colômbia (Senghas, 1991) e Brasil. No Brasil ocorre nos estados do Amazonas, Pará e Rondônia, em floresta de igapó.

Florescimento: Floresce de fevereiro a outubro.

Material examinado: Brasil. Amazonas: Lago do Janauacá, Italiano, furo da Terra Firme, 9/VII/1969, Byron 212 (INPA); Santa Izabel do Rio Negro, Igarapé do Daará, 14/X/1978, Braga et al. PFE 251 (HB). Rondônia: Porto Velho, UHE 
de Samuel, Rio Jamari, 11/II/1989, Maciel \& Rosário 1692 (MG).

G. lacustris caracteriza-se por apresentar o lobo mediano bastante pronunciado, deixando as carenas expostas, diferentemente das outras espécies nas quais as carenas se localizam mais internamente. A superfície ventral da coluna é vilosa, como em G. stangena, no entanto difere desta por não apresentar indumento lanoso no ápice das carenas. Barbosa Rodrigues escolheu o epíteto específico de G. lacustris, em virtude da espécie crescer epifiticamente em áreas alagadas.

O material-tipo de G. d'escagnolleana Rchb.f., considerada sinônimo de G. lacustris, foi citado para o estado do Pará mas, até o presente, nenhum material de G. lacustris foi encontrado no referido estado.

3. Galeandra devoniana Schomb. ex Lindl., Sert. Orchid. t. 37. 1840.

\section{FIGURA 3}

Epífita. Pseudobulbos fusiformes, $50-80 \mathrm{~cm}$ compr., $0,45-1,27 \mathrm{~cm}$ diâm. Folhas lineares a linear-lanceoladas, 7,8 $-25,6 \mathrm{~cm}$ compr., $6-14 \mathrm{~mm}$ larg. Inflorescência paniculada, $1-7$ flora, $11-24,5 \mathrm{~cm}$ compr., subpêndula; pedúnculo verde-claro, 9,5-20 cm compr., recoberto por uma ou mais brácteas; brácteas do pedúnculo $10-35 \mathrm{~mm}$ compr.; raque verde-claro, $2,5-4,5 \mathrm{~cm}$ compr. Ovário pedicelado verdeclaro, $24-38 \mathrm{~mm}$ compr., bráctea floral $6-12 \mathrm{~mm}$ compr. Flores grandes, aromáticas. Sépalas castanho-avermelhadas com nuances verdes, bordo mais claro, em alguns casos sépalas e pétalas podem estar parcialmente ou totalmente curvadas para frente; sépala dorsal com $30-50 \mathrm{~mm}$ compr., 5-9 mm larg.; sépalas laterais com as mesmas medidas da sépala dorsal ou pouco mais largas. Pétalas $33-49 \mathrm{~mm}$ compr., $6-11 \mathrm{~mm}$ larg., levemente recurvadas no ápice. Labelo suborbicular até rômbico-obovado, $31-52 \mathrm{~mm}$ compr., 50 - $56 \mathrm{~mm}$ de larg., branco ou branco-amarelado com listras lilases a vináceas no lobo mediano, na porção mediana externa listras castanhoavermelhadas que vão até o calcar, ápice obtuso, margem crenulada, lâmina papilosa, principalmente no disco e no ápice; disco com 4 carenas amarelo-esverdeadas, pubérulas, as externas bastante delgadas; calcar retuso com ápice agudo, verde com listras castanho-avermelhadas, internamente glabro ou esparsamente pubérulo. Coluna glabra ou esparsamente pubérula, branca com manchas vináceas na superfície ventral, 15-20 mm compr., 3-4 mm larg. Antera branco-amarelada. Polinário com estipe laminar, formato de " $\mathrm{T}$ " invertido.

Distribuição geográfica: Epífita de áreas de igapós e florestas ciliares. Em território brasileiro encontra-se nos estados do Amazonas e Pará (município de Oriximiná). Fora do Brasil é encontrada na Venezuela e na Guiana (Pabst \& Dungs, 1975).
Florescimento: Floresce de dezembro a outubro, as flores duram até quatro semanas.

Material examinado: Brasil: Amazonas: Rio Negro, 4/ IV/1949, Addison s/n (IAN 44219); Projeto RADAM -subbase R. Uneiuxi, 07/VI/1976, Marinho 445 (IAN); Projeto RADAM - sub-base Rio Mariê, 17/VI/1976, idem 563 (IAN); São Felipe, Rio Negro, 23/IX/1952, Froés 28704 (IAN); Tapereira and São Tomé and vicinity, 29/VI/1979, Poole 1761 (INPA); Rio Cuieras, perto do rio Branquinho, em igapó, 29/IV/1978, Braga 2511 (INPA); rio Negro, no rio Waupés, município de São Gabriel da Cachoeira, 08/XII/1978, Damião 3053 (INPA); Igarapé Taruma-açú, near Manaus, 04/I/1981, Nelson \& Nelson 954, (INPA); Rio Uneiuxi, campina do Dodono, 26/X/1971 Prance et al. (INPA 33819); Rio Preto, igapó, 29/V/1964, Rodrigues \& Coelho 5861, (INPA); Rio Negro, no caminho entre o remanso de Camanaus e Curicuriari, a $3 \mathrm{Km}$ da boca do Curicuriari, 07/V/1973, Silva et al. 1652 (INPA); Rio Cuieiras, afluente do rio Negro,

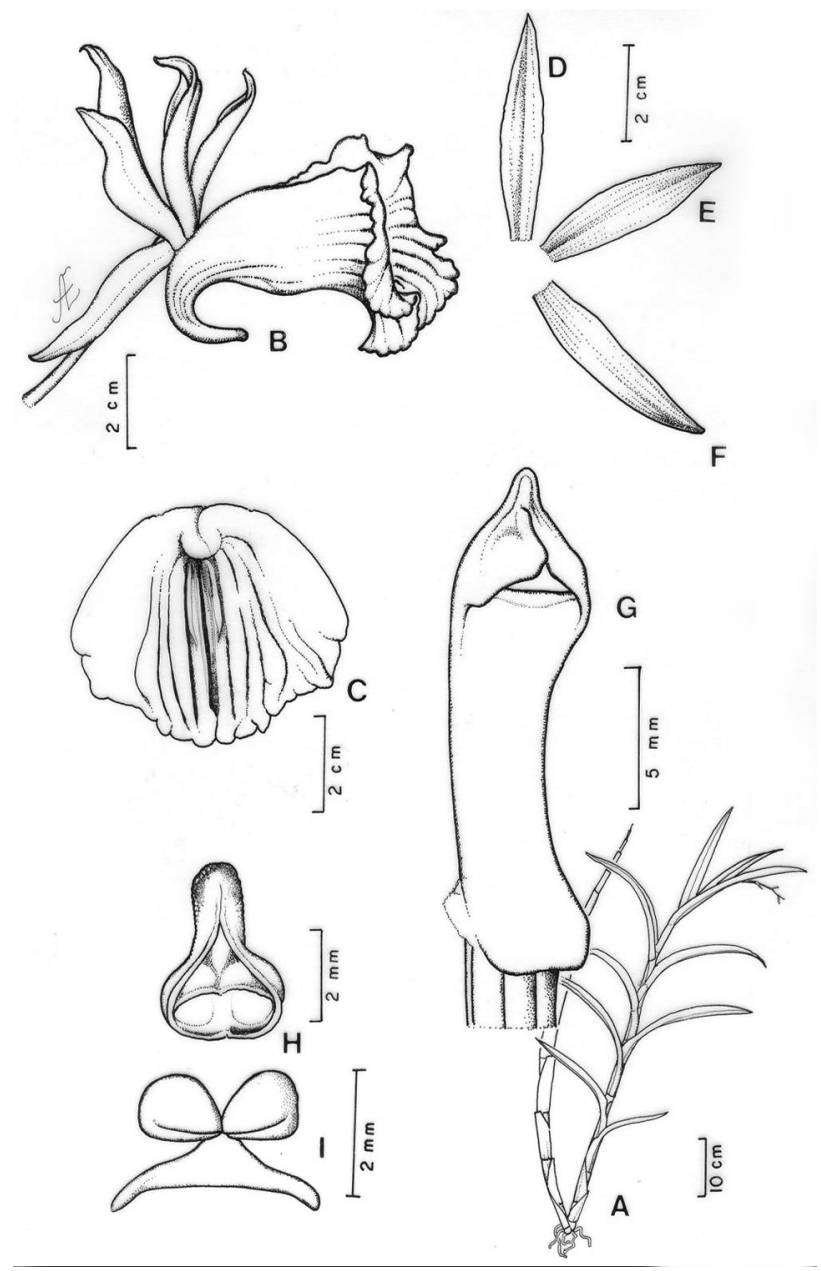

Figura 3 - Galeandra devoniana. A hábito. B flor inteira. C labelo (lâmina aberta). D sépala dorsal. E pétala. F sépala lateral. G coluna. H antera (vista frontal). I polinário. 
perto do rio Branquinho em igapó, 29/IV/1975, .Braga 2912 (INPA); Rio Urubu, between factory and Manaus-Itacoatiara Road, 10/VI/1968, Prance et al. (INPA 5100); Rio Negro, rio Cuieiras, lago Jaradá, 21/VI/1992, Mori \&. Gracie (INPA 22424); Rio Cuieiras, $60 \mathrm{Km}$ from mouth at locality called Jaradá, 09/VI/1990, Mori et al. (INPA 21259); Rio Natal, afluente do rio Uneiuxi., por sua vez afluente do rio Negro, III/83, Genaro (INPA 109871); Manaus, rio Tarumã-Mirim ou tarumãzinho, 04/II/1991, Silva \& Silva 41 (MG); Pará: Oriximiná, Silva 811 (MG).

Galeandra devoniana distingue-se das demais espécies por ter o labelo com listras lilases a vináceas e calcar internamente glabro ou esparsamente pubérulo, completamente curvado em direção ao centro do labelo. A região central da lâmina e a dos lobos, que nas demais espécies é pubérula, nesta espécie possui papilas. O epíteto específico é uma homenagem ao duque de Devonshire.

4. Galeandra curvifolia Barb. Rodr., Gen. Sp.

Orchid. 1: 85. 1877.

\section{FIGURA 4.}

Epífita. Pseudobulbos fusiformes, $7-18 \mathrm{~cm}$ compr., $0,8-1,1 \mathrm{~cm}$ diâm. Folhas linear-lanceoladas, $8,5-23 \mathrm{~cm}$ compr., $6-14 \mathrm{~mm}$ larg. Inflorescência paniculada, $1-3$ flora, pêndulas, $6,0-7,6 \mathrm{~cm}$ compr.; pedúnculo verde a verde-pardacento, $3,6-4,7 \mathrm{~cm}$ compr., recoberto por poucas brácteas; brácteas do pedúnculo de $11-28 \mathrm{~mm}$ compr.; raque verde-clara a verde-pardacenta, $2,4-2,9 \mathrm{~cm}$ compr. Ovário pedicelado verde a verde-claro, $20-25 \mathrm{~mm}$ compr., bráctea floral com 2-7 mm compr. Flores de tamanho médio. Sépalas amarelas com estrias castanho-avermelhadas; sépala dorsal, algo encurvada, 20 - $23 \mathrm{~mm}$ compr., 4 - 4,5 $\mathrm{mm}$ larg.; sépalas laterais ligeiramente oblíquas, $21-24 \mathrm{~mm}$ compr., $3-4 \mathrm{~mm}$ de larg. Pétalas $20-25 \mathrm{~mm}$ compr., 4,5 - $5 \mathrm{~mm}$ larg. Labelo rombico, $35-60 \mathrm{~mm}$ compr., $39-48 \mathrm{~mm}$ larg., branco a branco-amarelado, com pequenas listras lilases a vináceas no lobo mediano e numerosas pintas seriadas da mesma cor na superfície interna dos lobos laterais, ápice emarginado, margem ondulado-crenada; disco composto por 4 carenas de tonalidade alaranjada, as externas arqueadas e espessas em direção à base, algumas vezes com pontuações lilases; calcar filiforme, com ápice atenuado, amarelado com listras marrom-avermelhadas, internamente pubérulo, ascendente. Coluna glabra ou esparsamente pubérula, branca com ou sem pontuaçôes de cor vinácea na parte ventral e no centro do dorso, $11-13 \mathrm{~mm}$ compr., 3,0 - 3,5 mm larg. Antera branco-amarelada. Polinário com estipe laminar, formato de "T" invertido.

Distribuição geográfica: até o momento Galeandra curvifolia só foi encontrada no estado do Pará, nos municípios de Monte Alegre e Santarém, ocorrendo em vegetação de

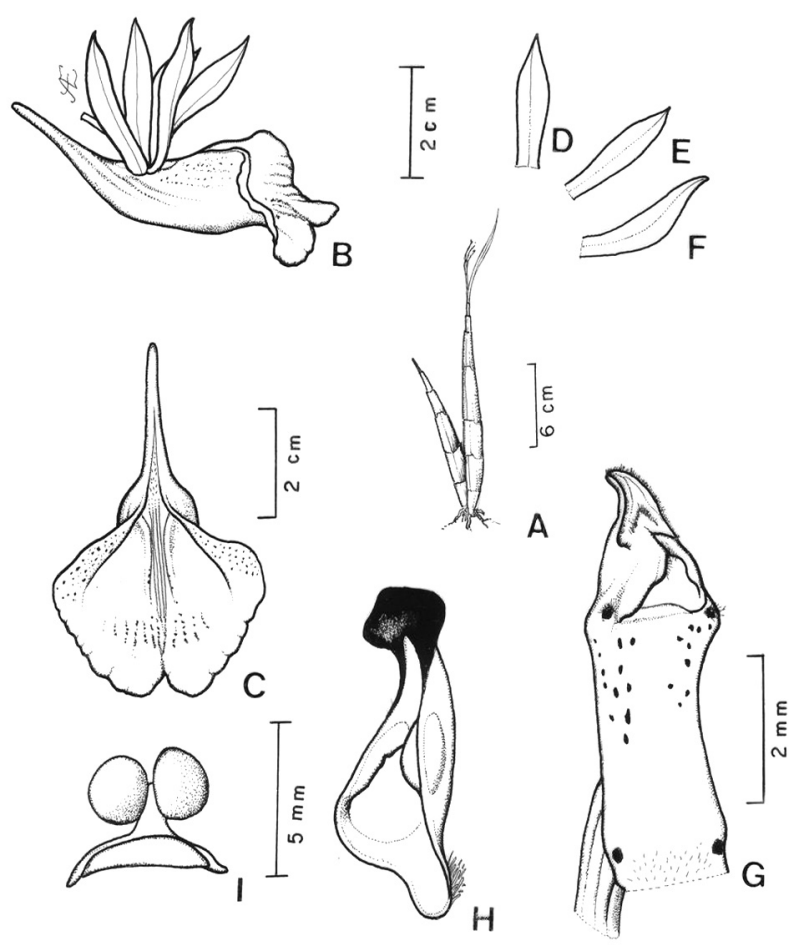

Figura 4 - Galeandra curvifolia. A hábito. B flor inteira. C labelo (lâmina aberta). D sépala dorsal. E pétala. $\mathbf{F}$ sépala lateral. $\mathbf{G}$ coluna. $\mathbf{H}$ antera (vista lateral). I polinário.

cerrado, habitando a palmeira-piririma (Syagrus coccoides Mart.).

Florescimento: Floresce de abril a maio.

Material examinado: Brasil: Pará: Monte Alegre, vegetação de cerrado pé da Serra da Lua, em Palmeira Syagrus sp., 22/V/1995, Silva 358, 423 (MG); base da Serra do Ererê, IV/1997, Silva 654 (MG); Santarém, comunidade São Braz, entre Santarém e Alter do Chão, VI/1999 , Silva 808 (MG).

Galeandra curvifolia é muito semelhante a $G$. baueri, mas difere desta por apresentar o labelo mais afunilado, a coluna mais estreita e as carenas externas menos espessas e não tão distantes entre si. Há uma grande variação na intensidade e na cor dos pigmentos violáceos do labelo. Os lobos podem aparecer com muitas e intensas pontuaçôes ou praticamente sem nenhuma.

5. Galeandra baueri Lindl., Ill. orch. pl. tab. 8. 1832. FIGURA 5.

Epífita. Pseudobulbos fusiformes, $16-23 \mathrm{~cm}$ compr., $0,83-1,5 \mathrm{~cm}$ diâm. Folhas oblongo-lanceoladas, $18-25,7$ cm compr., 1,6-2,1 cm larg. Inflorescência paniculda, 4- 16 flora, pêndula ou sub-pêndula, ca. $7 \mathrm{~cm}$ comp., pedúnculo 
verde-pardacento, 2,5-4,0 cm comp., recoberto por poucas brácteas; brácteas do pedúnculo $9-13 \mathrm{~mm}$ compr.; raque verde, 3,0 - 4,5 cm compr. Ovário pedicelado verde-claro, 20 - $25 \mathrm{~mm}$ compr., bráctea floral ca. $5 \mathrm{~mm}$ compr. Flores de tamanho médio. Sépalas amarelo-esverdeadas com listras castanho-avermelhadas; sépala dorsal ereta ou encurvada, 23 - $28 \mathrm{~mm}$ compr., $4-6 \mathrm{~mm}$ larg.; sépalas laterais eretas ou levemente encurvadas, $25-28 \mathrm{~mm}$ compr., ca. 6,5 $\mathrm{mm}$ larg. Pétalas eretas ou $23-24 \mathrm{~mm}$ compr., $6,5-7 \mathrm{~mm}$ de larg. Labelo rômbico a rômbico-obovado, $54-62 \mathrm{~mm}$ compr., ca. $48 \mathrm{~mm}$ larg., amarelo-esbranquicado, ápice emarginado, margem crenada; disco composto por 4 carenas alaranjadas, pubérulas, as externas ligeiramente curvas e espessas em direção à base; calcar filiforme, com ápice atenuado, esverdeado ou amarelo-ouro, com algumas listras castanhas na superfície ventral, ascendente, com ápice ligeiramente curvado para cima, internamente pubescente. Coluna glabra ou esparsamente pubérula, branco-amarelada, com algumas pintas vináceas na superfície ventral, ca. $13 \mathrm{~mm}$ compr., ca. 4,5 mm larg. Antera branco-amarelada, Polinário com estipe laminar, formato de "T" invertido.

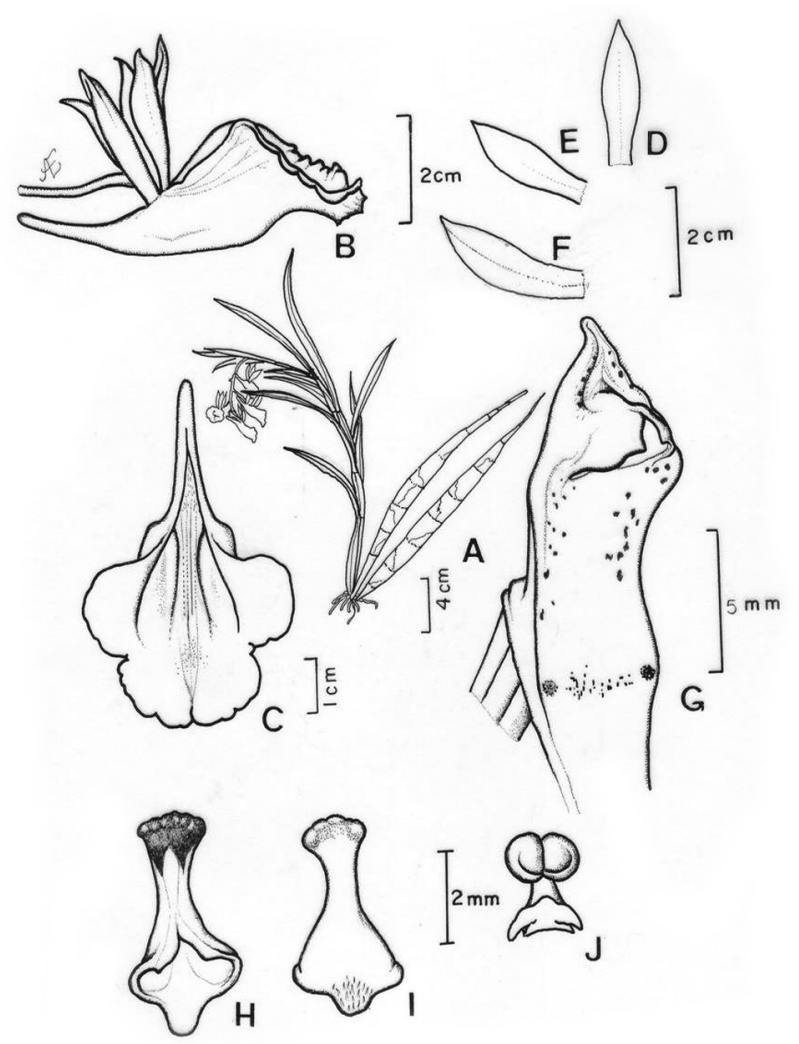

Figura 5 - Galeandra baueri. A hábito. B flor inteira. C labelo (lâmina aberta). D sépala dorsal. E pétala. F sépala lateral. $\mathbf{G}$ coluna. $\mathbf{H}$ antera (vista frontal). I antera (vista dorsal). J polinário.
Distribuição geográfica: no Brasil encontra-se no estado do Amapá, como epífita sobre palmeiras (Bactris sp.), às margens de igarapés em áreas de vegetação de cerrado (matas de galeria) e no estado do Pará encontra-se em florestas abertas sobre palmeiras nas encostas de morros. É citada também para Guiana Francesa, Peru, Colômbia, Venezuela e América Central (Pabst \& Dungs, 1975).

Florescimento: Floresce de abril a maio. As flores duram em média três semanas.

Material examinado: Brasil: Pará: Santarém, VI/1999, Silva 815 (MG). Amapá: Tartarugalzinho, Fazenda Teimoso, IV/1997 Silva, 658 (MG).

Galeandra baueri é a espécie-tipo do gênero. Diferencia-se das demais pelas carenas externas que engrossam em direção à base, enquanto que as outras espécies têm as carenas externas engrossadas em direção ao ápice, com exceção de G. curvifolia, na qual as carenas também são engrossadas na base. No entanto, G. baueri difere desta espécie em vários aspectos: as carenas são mais distantes entre si e mais espessas, a abertura e curvatura na base são mais acentuadas, a base do labelo é mais larga e com as laterais pronunciadas.

6. Galeandra styllomisantha (Vell.) Arq. Bot. Estado São Paulo. II: 146. 1952.

Orchis styllomisantha Vell., Fl. Flum. 9: t. 46. 183. 1831.

Galeandra juncea Lindl., Sert. orchid. sub I. 37. 1840.

Phajus rosellus Lem., Fl. Serres Jard. Paris. 3: t. 301. 1847.

FIGURA 6.

Terrestre. Pseudobulbos ovóides ca. 2,5 cm compr., ca. 1,0 $\mathrm{cm}$ diâm. Folhas estreitamente-lineares, $25-32 \mathrm{~cm}$ compr., $8-11 \mathrm{~mm}$ larg. Inflorescência paniculada, 3 - 5 flora, ereta, ca. $73 \mathrm{~cm}$ compr., pedúnculo verde claro, ca. $61 \mathrm{~cm}$ compr., recoberto por poucas brácteas; brácteas do pedúnculo $15-45$ mm compr.; raque verde-clara a pardacenta, ca. $12 \mathrm{~cm}$ compr. Ovário pedicelado, verde-esbranquiçado a branco-rosado, ca. $18 \mathrm{~mm}$ compr., bráctea floral $3-6 \mathrm{~mm}$ compr. Flores pequenas. Sépalas lilás-esbranquiçadas, algo encurvadas; sépala dorsal ca. $12 \mathrm{~mm}$ compr., ca. 4,4 $\mathrm{mm}$ larg.; sépalas laterais, ca. $13 \mathrm{~mm}$ compr., ca. 4,4 mm larg. Pétalas ca. 12 $\mathrm{mm}$ compr., ca. $4 \mathrm{~mm}$ larg. Labelo rômbico-obovado 20 - 22 $\mathrm{mm}$ compr., ca 1,8 mm larg., lilás-claro com pequenas listras vináceas, principalmente no lobo mediano, ápice retuso, margem crenulada; disco composto por 4 carenas brancorosadas, pubescentes, as externas espessas em direção ao ápice; calcar filiforme, com ápice atenuado, amarelo-ouro, levemente curvado para baixo, internamente pubescente. Coluna glabra ou esparsamente puberula, branca, ligeiramente encurvada, algumas papilas de coloração violácea nas bordas do ápice, 7 - 8 mm compr., ca. 1,7 mm larg. Antera branca. Polinário laminar, formato de " $\mathrm{T}$ " invertido. 
Distribuição geográfica: G. styllomisantha ocorre no Panamá, Venezuela, Colômbia, Bolívia, Peru, Guiana, Suriname e Guiana Francesa e Brasil (Werkhoven, 1996). No Brasil é encontrada em Roraima, Pará, Amapá, Tocantins, Mato Grosso, Goiás, Distrito Federal, Maranhão, Minas Gerais e Paraná. Cresce ocasionalmente em campos limpos estacionalmente úmidos, campos limpos adjacentes a matas de galerias e brejos adjacentes a campos. Algumas anotaçôes em exsicatas mencionam que o florescimento acontece logo após queimadas nos campos de Cerrado. Nós campos do Amapá esse fato é comum (J.B.F da Silva, com. pess.).

Florescimento: Floresce de dezembro a outubro.

Material examinado: Brasil: Roraima: Boa Vista, at a distance of $50 \mathrm{~km}$ (BR 401), 15/X/1977, Coradin \& Corediro s.n. (INPA 185707); Rio Branco, Boa Vista, campo de aviação, 16/VIII/1951, Black 51-12560 (IAN); Rio Branco, IX/1909, Ule 8110 (MG). Pará: Ilha de Marajó, Vila de Maracá e Salvaterra, XI/1969, Lacerda \& Guedes (IAN 153255); Muaná, margem esquerda do rio Anijabú, em frente à fazenda Espírito Santo, 22/VI/1982, Dantas \& Nivaldo 1079 (IAN); Muaná, rio Anijabú, em frente à fazenda Rosário 22/VI/1982, Dantas \& Nivaldo 1053 (IAN); Almeirim, 08/IV/1903, Ducke (MG 3437). Amapá: Quadrícula SB - 22 - VA - ponto 44, 09/ IV/1982, Rosa et al. 4230 (INPA); próximo de Santana, 22/ IV/1982, Rosa et al. 4247 (MG); Km 48, Pires \& Cavalcante (MG 29354); Macapá, 22/IV/1926, Ducke s.n. (RB 19436). Tocantins: Área cerca de $50 \mathrm{~km}$ a Oeste de Natividade (saída para São Valério), próximo ao Rio Manoel Alves da Natividade. fazenda Santa Maria, 19/II/1997, Batista 695 (CEN); área a direita da pista, cerca de 18-20 Km após Araguaçu, na estrada para Alvorada, 16/II/1997, Batista 684 (CEN); Ilha do Bananal, Santa Izabel, Parque Nacional do Araguaia, 20/VI/1979, Silva et al. 240 (UB). Mato Grosso: Cáceres, I/1909, Hoehne 1129 (R); Tapirapoan, III/1909, Hoehne 1516, 1517 (R); Expedition Base Camp: 12 49' S., 51 46' W, 9/I/1968, Philcox \& Ferreira, 4508 (UB); Xavantina-Cachimbo road, 10/III/1968, Philcox \& Ferreira, 3947 (UB); Arrayollos, 23/IV/1903, Ducke (MG 3518). Goiás: Pirenópolis: Santuário de Vida Silvestre Morro do Cabeludo, 19/II/95, Batista \& Bianchetti 539 (CEN), Morro do Cabeludo, 17/I/1992, Batista 160, 235 (CEN) ; Minaçú, próximo a área de empréstimo de argila ME 33, 10/III/1992, Cavalcante 1128 (CEN, SP); Uruaçú, BR - 153, passando pela Vila água Branca, 07/II/96, Teles et al. s.n. (CEN 027721, SP 319790); Córrego Santo Antônio, 7 Km SSE de Goiás Velho, 06/I/1984, Kirkbride Jr. (UB 5520) Serra Geral do Paranã, ca. 10 Km of São João da Aliança, 17/III/1971, Irwin32068 (UB); ca. 5 km of Niquelândia, 25/I/1972, Irwin, et al. 35000 (UB); Distrito Federal: Fazenda Água Limpa, a 9 km da Reserva Ecológica do IBGE, Bacia dos Corrégos, 14/XII/1989, Neto \& Silva s.n. (SP 238668). Maranhão: Município de Carolina,

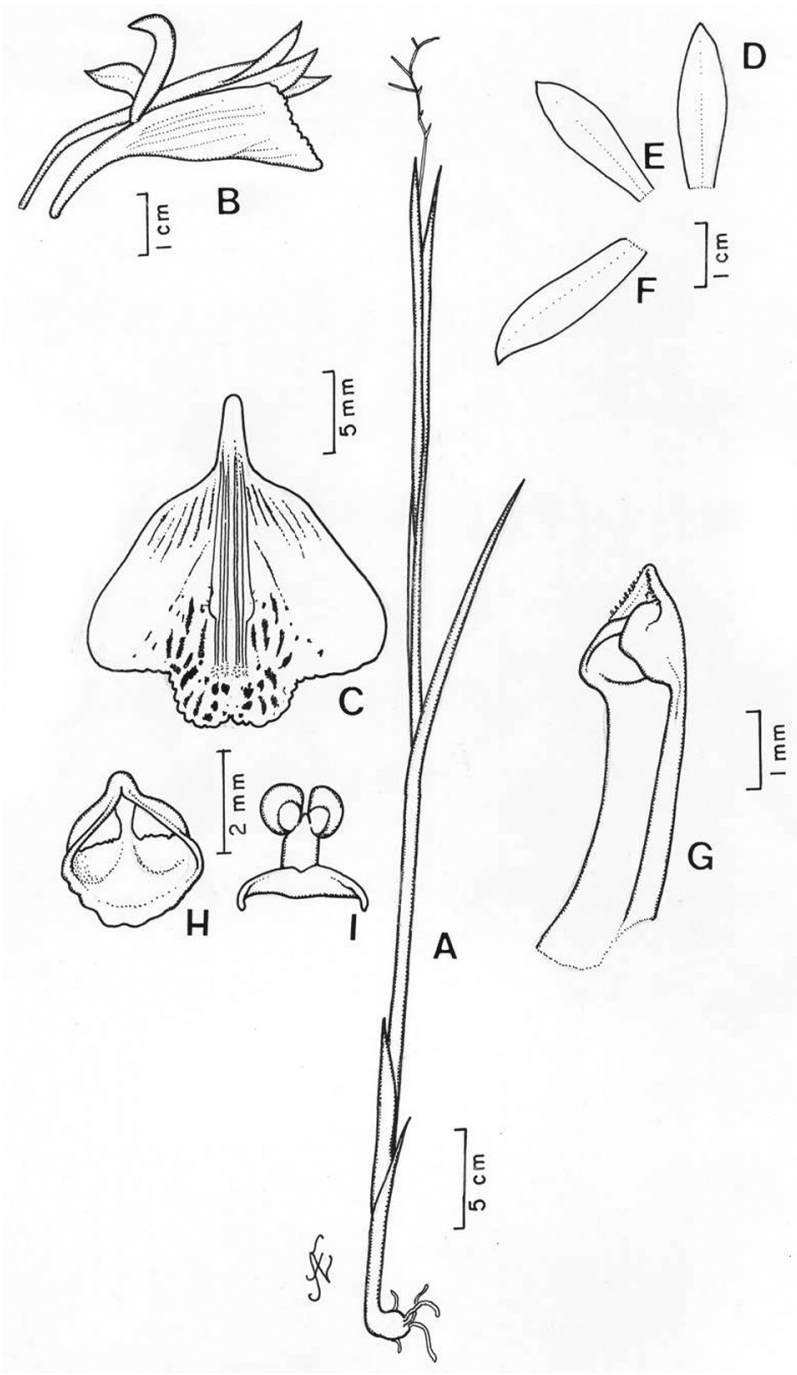

Figura 6 - Galeandra styllomisantha. A hábito. B flor inteira. C labelo (lâmina aberta). D sépala dorsal. E pétala. F sépala lateral. G coluna. $\mathbf{H}$ antera (vista frontal). I polinário.

22/V/1996, Silva 542 (MG). Minas Gerais: Serra do Cabral, ca. $2 \mathrm{~km} \mathrm{W.} \mathrm{of} \mathrm{Cantoni,} \mathrm{8/III/1970,} \mathrm{Irwin} \mathrm{s.n.} \mathrm{(UB} \mathrm{38313);}$ Santana do Riacho, estrada Lagoa Santa - Conceição do Mato Dentro, Serra do Cipó, 03/II/1987, Wendt \& Vitta (RB 254365). Paraná: Guaíra, Sete Quedas, 13/XII/1963, Pereira 7871 \& Hatschbach 10486 (RB).

Galeandra styllomisantha diferencia-se das demais espécies terrestres por ter o calcar filiforme, assim como G. paraguayensis, mas distingue-se desta por apresentar labelo com pequenas listras vináceas no lobo mediano, ápice obtuso-emarginado, além de pétalas e sépalas da mesma cor do labelo. 
7. Galeandra paraguayensis Cogn., Bull. Herb. Boissier. ser. 2, 3: 933.1903

Galeandra paranaensis Schltr., Repert. Sp. Nov. Regni Veg. 16: 331. 1920.

FIGURA 7.

Terrestre. Pseudobulbos ovóides ca. 2,5 cm compr., ca. $2 \mathrm{~cm}$ diâm. Folhas lanceoladas, 5,5 - $15 \mathrm{~cm}$ compr., 6 $14 \mathrm{~mm}$ larg. Inflorescência paniculada, 1 - 3 flora, eretas ou subpêndulas, $24-30 \mathrm{~cm}$ compr,; pedúnculo, esverdeado, $20-23,7 \mathrm{~cm}$ compr., recoberto por várias brácteas; brácteas do pedúnculo $14-23 \mathrm{~mm}$ compr.; raque esverdeada, 2,2 $6,3 \mathrm{~cm}$ compr., Ovário pedicelado, verde-claro, $14-22 \mathrm{~mm}$ compr., bráctea floral $5-10 \mathrm{~mm}$ compr. Flores médias. Sépalas esverdeadas, rajadas de violeta, encurvadas; sépala dorsal, 21 $35 \mathrm{~mm}$ compr., 7 - $8 \mathrm{~mm}$ larg., sépalas laterais $23-40 \mathrm{~mm}$ compr., 7 - $9 \mathrm{~mm}$ larg. Pétalas $22-33 \mathrm{~mm}$ compr., ca. 7 $\mathrm{mm}$ larg., recurvadas no ápice. Labelo rômbico, $30-41 \mathrm{~cm}$ compr., $20-25 \mathrm{~cm}$ larg., esverdeado com listras violáceas na parte interna dos lobos laterais, lobo mediano esbranquiçado com listras rosadas, ápice longamente acuminado, margem do lobo mediano levemente crenada e a dos lobos laterais lisas; disco composto por 4 carenas esverdeadas, pubescentes, as externas espessas em direção ao ápice; calcar filiforme, com ápice atenuado, descendente, internamente pubescente a pubescente-viloso. Coluna pubérula, branco-esverdeada, 11 - $13 \mathrm{~mm}$ compr., 3-3,5 mm larg. Antera branco-amarelada. Polinário com estipe laminar, formato de " $T$ " invertido.

Distribuição geográfica: ocorre no Distrito Federal e nos estados de Goiás, Mato Grosso e Paraná, habitando campos de murundus, margens de córregos adjacentes a campos e campos limpos com solos úmidos. É encontrada também no Paraguai.

Florescimento: floresce de novembro a dezembro.

Material examinado: Brasil. Mato Grosso: Porto Espiridião, XI/1908, Hoehne 870/871 (R), XI/1908, Hoehne 870 (R); S. of Cristalina, 05/XI/1965, Irwin et al. (UB 40170). Goiás: Cristalina, Santuário de Vida Silvestre Linda Serra dos Topázios, 18/XII/94, Batista 441 (CEN); Próximo a Anápolis, 25/XI/1964, Heringer 9954 (HB). Distrito Federal: buritizal próximo de Brasília, 02/XII/1957, Castellanos 21802 (R); Brasília, Várzea Bonita, 17/XI/1961, Heringer 8752 (SP); Reserva do Guará, 18/XI/1994, Oliveira 025 (UB). Paraná: Palmeira, km 60 da rodovia Curitiba - Ponta Grossa, 08/ XII/1965, Leinig 359 (HB).

No grupo das espécies terrestres, Galeandra paraguayensis aproxima-se de G. styllomisantha pelo calcar filiforme. No entanto, estes dois táxons podem ser diferenciados por apresentarem diferença no lobo mediano e na coloração nas peças florais. G. paraguayensis possui sépalas e pétalas com
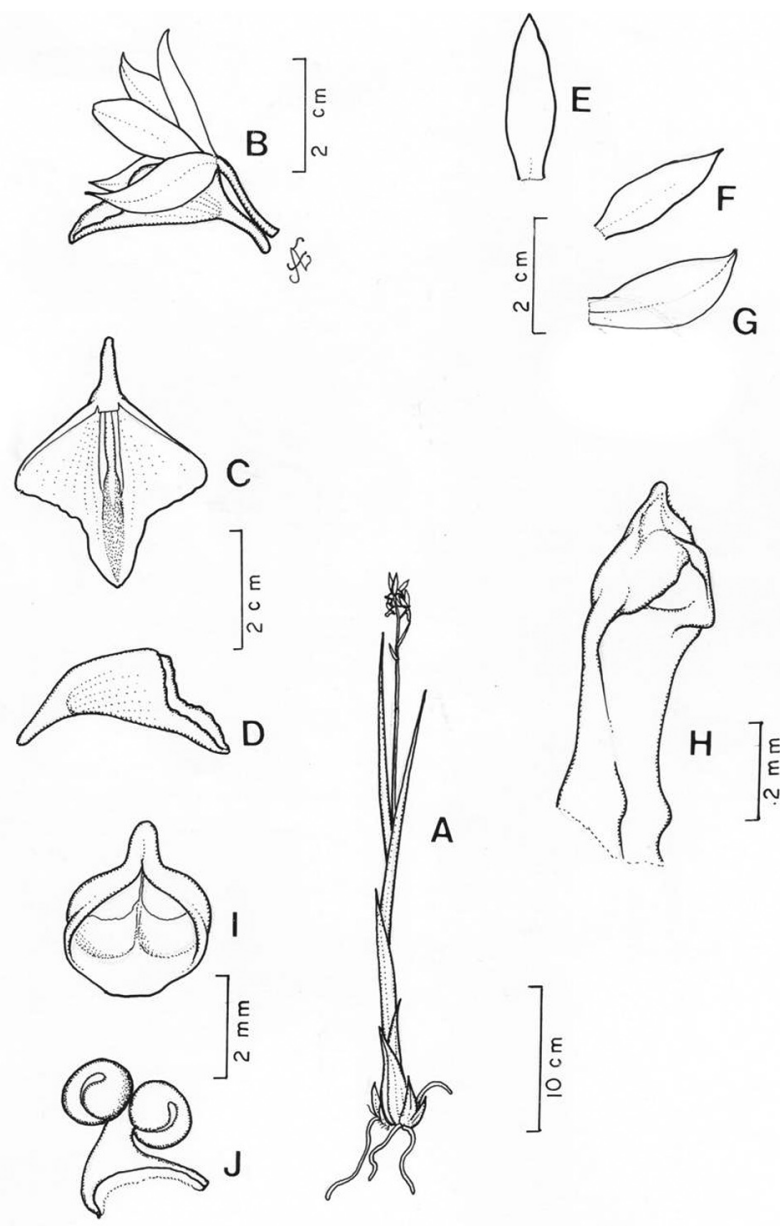

Figura 7 - Galeandra paraguayensis. A hábito. B flor inteira. C labelo (lâmina aberta). D labelo (vista lateral). E sépala dorsal. F pétala. G sépala lateral. H coluna. I antera (vista frontal). J polinário.

cores diferentes do labelo e lobo mediano sem listras vináceas com ápice longamente acuminado.

8. Galeandra beyrichii Rchb.f., Linnaea, 22: 854. 1849. Galeandra viridis Barb. Rodr., Revista Engen. 3(9): 143. 1881. Galeandra coxinnensis Hoehne, Relat. Commiss. Linhas. Telegr. Estratég. Matto Grosso Amazonas. 4: 15, t. 70. 1912.

Galeandra fiebrigii Schltr., Repert. Sp. Nov. Regni Veg. 10: 47. 1922.

\section{FIGURA 8.}

Terrestre. Pseudobulbos ovóides, $1-2,5 \mathrm{~cm}$ compr. Folhas não observadas, ausentes durante a floração. Inflorescência racemosa, $6-16$ flora, ereta, $40-1,10 \mathrm{~cm}$ compr., pedúnculos, esverdeados, $28-95,8 \mathrm{~cm}$ compr., revestido por várias brácteas; brácteas do pedúnculo $30-100 \mathrm{~mm}$ compr.; raque esverdeada, $7-33 \mathrm{~cm}$ compr., bráctea floral 
, 30 - $42 \mathrm{~mm}$ compr. Ovário pedicelado verde-claro, 17 $36 \mathrm{~mm}$ compr., bráctea floral $8-20 \mathrm{~mm}$ compr. Flores de tamanho médio. Sépalas amarelo-esverdeadas; sépala dorsal ereta ou encurvada, $22-32 \mathrm{~mm}$ compr., $4-6 \mathrm{~mm}$ larg., sépalas laterais encurvadas, $20-31 \mathrm{~mm}$ compr., $4,5-7 \mathrm{~mm}$ larg. Pétalas 17 - 3,1 mm compr., $4-7 \mathrm{~mm}$ larg. Labelo rômbico-obovado, ligeiramente pouco trilobado, $15-24 \mathrm{~mm}$ compr., 20 - $30 \mathrm{~mm}$ larg., branco-amarelado com nervuras esverdeadas longitudinais na parte externa, lobos pubescente, com pequenas listras vináceas, ápice retuso, margem crenada; disco composto por 4 carenas esverdeadas, pubescente-vilosas, as externas espessas em direção ao ápice; calcar cônico, com ápice obtuso, esverdeado ou amarelo-ouro, com nervuras esverdeadas, descendente, internamente pubescente a pubescente-viloso. Coluna pubérula, esverdeada, $8-11 \mathrm{~mm}$ compr., 3-4,5 mm larg. Antera branco-amarelada. Polinário com estipe laminar, formato de " $\mathrm{T}$ " invertido.

Distribuição geográfica: Galeandra beyrichii encontra-se desde o sul da Flórida, México, América Central, Venezuela, Colômbia, Peru e Bolívia (Foldats, 1970), até o Paraguai. No Brasil é encontrada no Mato Grosso, Goiás, Distrito Federal, Minas Gerais, Espírito Santo, Rio de Janeiro, São Paulo, Paraná, Santa Catarina e Rio Grande do Sul, ocorrendo em matas umbrófilas e em matas úmidas de altitude.

Florescimento: Floresce de janeiro a dezembro.

Material examinado: Brasil: Mato Grosso: Maribondo, São Lourenço, VI/1911, Hoehne 4115 (R); Coxim, V/1911, Hoehne 4113 (R). Goiás: Colinas do Sul, 12/III/92, Cavalcante et al. 1213 (CEN); Serra Geral do Paranã, São João da Aliança, 21/III/1973, Anderson 7513 (UB). Distrito Federal: Parque do Guará, 24/II/1961, Heringer 7991, (UB). Minas Gerais: Município Uniaí, localidade denominada Palmital, 27/IV/1993, Pereira \& Alvarenga (CEN 17750); São Gonçalo do rio Abaixo, 10/II/1994, Borba 121 (BHCB); Estação Ecológica da UFMG, Belo Horizonte, 25/III/1996, Lombardi 1149 (BHCB); Cambuquira, Juca Casimiro, 25/ XII/1935, Barreto 5473 (SP); Espírito Santo: V/1964, Machado 94 (HB); Domingos Martins, 28/VII/1972, Kautsky 360 (HB). Rio de Janeiro: Barra do Piraí, Ipiabas, Fazenda da Floresta, 05/02/1989, Laclette 911 (R); Floresta da Tijuca, 18/ XI/1931, Brade 10585 (R); Corcovado, estrada do Redentor I/1934, Freire 440 (R); Rezende, 3/III/1931, Holmes 06 (SP), Tijuca, IX/1916, Hoehne 226 (SP); Próximo à Vista Chinesa, 11/I/1963, Pereira 7248 (HB); Próximo a Nova Friburgo, 5/I/1970, Dungs (HB 43033); Itatiaia, 25/II/1942, Brade 17192 (RB). São Paulo: Morro das Pedras, II/1921, Brade (HB 8530); Mogi das Cruzes, 14/I/1912 (HB 8396); Vale do Paraíba, Taubaté, IV/1952, Welter 06 (HB); Rio Periquera Mirim, XII/1910, A.C.Brade (HB 8399); Angatuba, Fazenda do serviço Florestal, 23/II/1966, Emmerich \& Dressler (HB 40920). Paraná: Cerro Azul, Morro Grande, 25/I/1974,
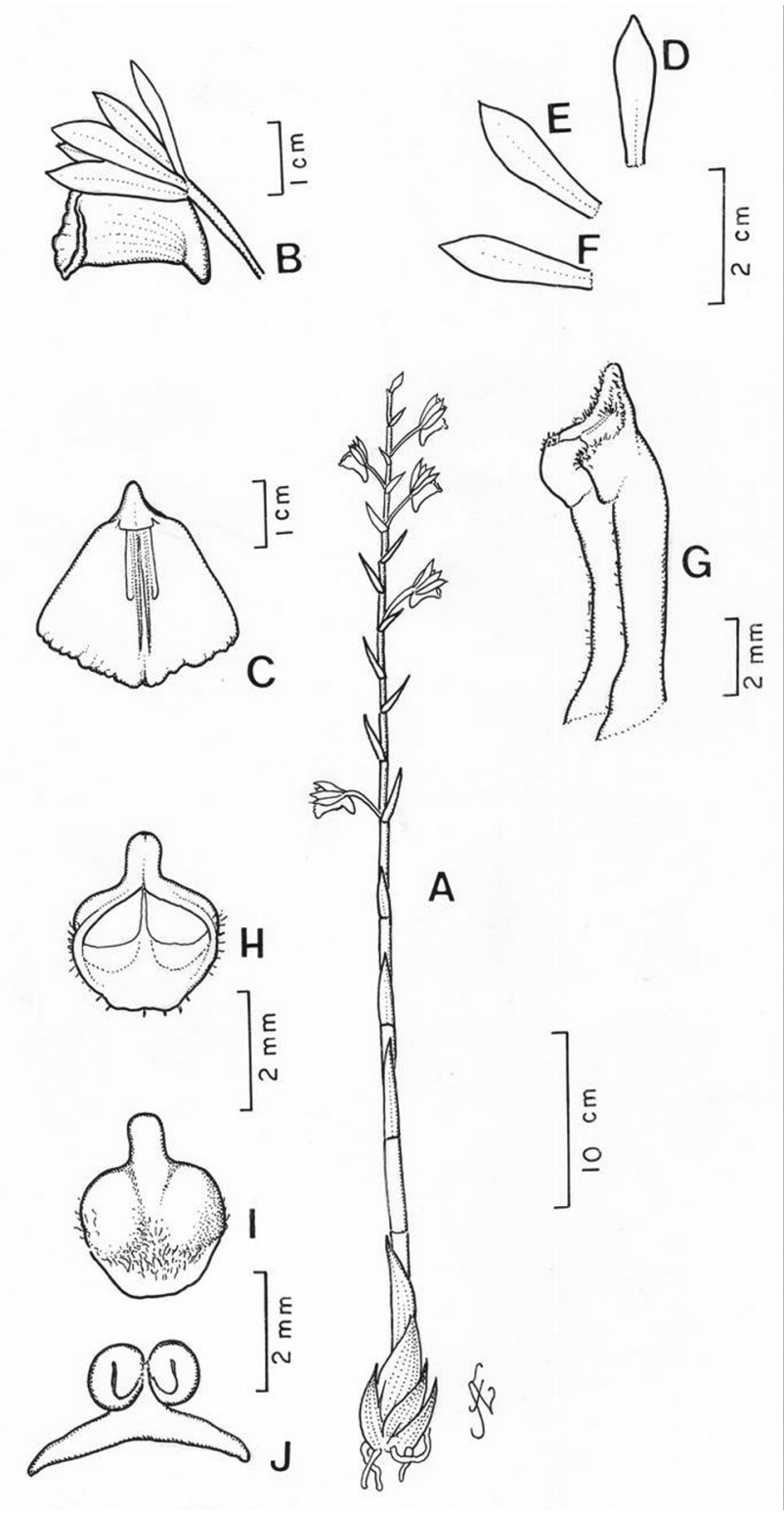

Figura 8 - Galeandra beyrichii. A hábito. B flor inteira. C labelo (lâmina aberta). D sépala dorsal. E pétala. $\mathbf{F}$ sépala lateral. $\mathbf{G}$ coluna. $\mathbf{H}$ antera (vista frontal). I antera (vista dorsal). J polinário.

Hatschbach 33761 (HB); Campina Grande do Sul, Ribeirão Grande, 19/XII/1967, Hatschbach 16195 (HB). Rio Grande do Sul: Porto Alegre, Morro da Glória, 10/I/1933, Rambo 262 (SP); Próximo de Rosário, 14/II/1974, Gonçalves (HB 63142); Boa Vista, Salvador do Sul, 2/I/1967, Klein (HB 41947); Entre Morro Reuter e Herval, I/1969, Frank (HB 42557); a $10 \mathrm{Km}$ de Gramado, 28/I/1963, Nelz(HB 20039). Paraguai: San Pedro: Alto Paraguai, próximo de Primavera, 17/I/1960, Woolston 1167 (HB, SP). 
Galeandra beyrichii distingue-se das demais espécies terrestres por ser totalmente áfila durante a floração, possuindo inflorescência racemosa, com a raque pluriflora $(6-16$ flores), o labelo é inconspicuamente trilobado e as brácteas do pedúnculo são estéreis. Aproxima-se de G. montana pelo formato do calcar, curto, cônico e obtuso. Mas diferencia-se desta espécie pelas características acima citadas e por possuir pequenas listras vináceas no lobo mediano e pelo calcar, internamente pubescente-viloso.

9. Galeandra montana Barb. Rodr., Revista Engen. 3(5): 73.1881.

Galeandra lagoensis Rchb. f. \& Warm., Otia Bot. Hamb. 2: 88(8). 1881.

\section{FIGURA 9}

Terrestre. Pseudobulbos ovóides, ca. $5 \mathrm{~cm}$ compr., ca 2,5 $\mathrm{cm}$ diâm. Folhas lanceoladas, $16,4-52 \mathrm{~cm}$ compr., $1,1-2,1$ $\mathrm{cm}$ larg. Inflorescência paniculada $2-3$ flora, subpêndulas, $37,5-74 \mathrm{~cm}$ compr., pedúnculo esverdeado, $24,2-45,6 \mathrm{~cm}$ compr., revestido por várias brácteas; brácteas do pedúnculo 6,1-14 cm compr.; raque esverdeada, 3,3-14,1 cm compr., bráctea floral $21-38 \mathrm{~mm}$ compr. Ovário pedicelado verdeclaro, $33-50 \mathrm{~mm}$ de compr., bráctea floral de $19-47 \mathrm{~mm}$ compr. Flores grandes. Sépalas verde-acastanhadas com tons avermelhados, eretas ou encurvadas, ápice reflexo; sépala dorsal, $28-31 \mathrm{~mm}$ compr., $6-8 \mathrm{~mm}$ larg., sépalas laterais $33-42 \mathrm{~mm}$ compr., $5-7 \mathrm{~mm}$ larg.. Pétalas $17-31 \mathrm{~mm}$ compr., $4-7 \mathrm{~mm}$ larg. Labelo rômbico-obovado, $42-45$ $\mathrm{mm}$ compr., 40 - $56 \mathrm{~mm}$ larg., branco-creme, lobo mediano violáceo, ápice obtuso, margem crenada; disco composto por 4 carenas branco-amareladas, pubérulas as externas espessas em direção ao ápice; calcar cônico, com ápice obtuso, amareloesverdeado com algumas listras avermelhadas nas laterais, descendente, internamente glabro ou esparsamente pubérulo. Coluna branco-amarelada, 13 - $15 \mathrm{~mm}$ compr., $4-7 \mathrm{~mm}$ larg. Antera branco-amarelada. Polinário com estipe laminar, formato de " $T$ " invertido.

Distribuição geográfica: Galeandra montana é encontrada nos estados do Pará, Mato Grosso, Goiás, Distrito Federal, Maranhão, Bahia e Minas Gerais, ocorrendo em campos rupestres, vegetação sobre canga, campos limpos e cerrados. Não há citação desta espécie para outros países.

Florescimento: Floresce de dezembro a julho.

Material examinado: Brasil. Pará: Óbidos, Rio Parú de Oeste (Tiriós), 01/VII/1960, Cavalcante 911 (MG); Região dos Tiriós, rio Paru do Oeste, 19/III/1962, Fittkau s.n. (INPA 12837); Região dos Tiriós, rio Paru do Oeste, igarapé Munení, 29/III/1962, Fittkau s.n. (INPA 12896); Monte Alegre, Serra Itauajury, 25/IV/1916, (RB 18718); Santarém, Silva 812 (MG). Mato Grosso: Salto Augusto, Juruena, II/1909-12,
Hoehne 5350/ 5351 (R); Encosta da Serra do Tapirapoan, I/1914, Hoehne 5604 (R); Cabeceira do rio Taquará-ussú, Chapada, III/1911, Hoehne 4116 (R). Goiás: Chapada dos Veadeiros, 09/II/1966, Irwin et al. 12409 (UB); Região Buração, perto da BR 020, 12/III/1981, Kirkbride s.n.(UB 4300); Distrito Federal: Cerrado, 30/I/1975, Heringer 14456 (UB); Brasília, Reserva Ecológica do Guará, 13/XI/1994, Miranda 014 (UB). Maranhão: Balsas, Condomínio Kissy, Lote 23, 09/III/96, Silva et al. (CEN 30169). Bahia: Salvador, Parque da Cidade, 14/VII/1987, Perez et al. 01 (MG); Espigão Mestre, ca. 100 km WSW of Barreiras, 06/III/1972, Anderson 36682 (UB); Porto Seguro, 25/VI/1962, Duarte 6823 (RB); Rui Barbosa, 14/VI/1978, Araújo 010 (RB). Minas Gerais: Serra do Taquaril, Belo Horizonte, 24/II/1933 Barreto 4833 (R, SP); Serra do Espinhaço, ca. $35 \mathrm{~km}$ of Gouveia, $\mathrm{km} 243$ on M.G. 259, 02/II/1972, Anderson et al. 35134 (UB); Caeté, Serra da Piedade, 24/IV/1985, José \& Grandi 1773 (BHCB); Nova Lima, Retiro das Pedras, estrada que liga a BR 040 ao Retiro, 14/II/1989, Irwin 27001 (UB).

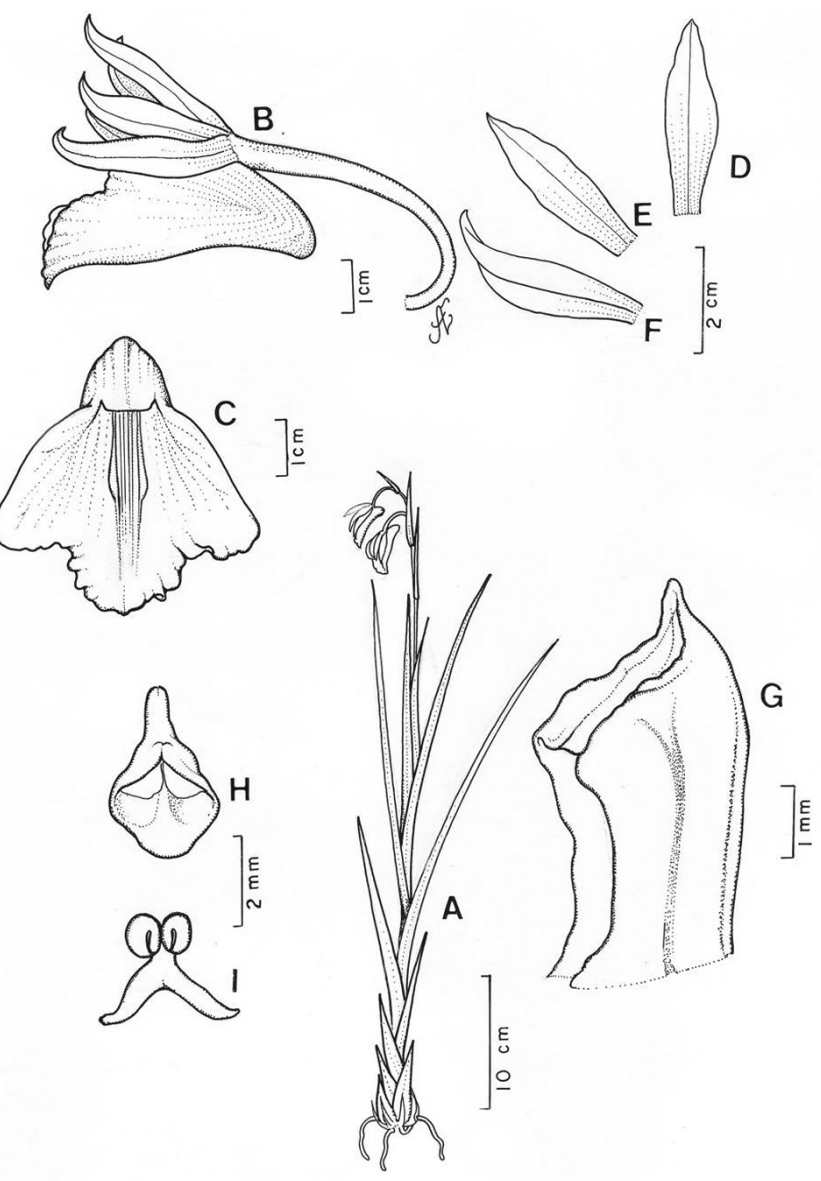

Figura 9 - Galeandra montana. A hábito. B flor inteira. C labelo (lâmina aberta). D sépala dorsal. E pétala. F sépala lateral. $\mathbf{G}$ coluna. $\mathbf{H}$ antera (vista frontal). I polinário. 
Galeandra montana distingue-se das demais espécies pelo formato do calcar, curto cônico e obtuso, assim como G. beyrichii. Porém difere desta por permanecer com folhas durante a floração, ter a inflorescência paniculada, lobo mediano vináceo, calcar internamente glabro ou esparsamente pubérulo.

\section{AGRADECIMENTOS}

Os autores agradecem aos curadores dos herbários nacionais pelo empréstimo do material, ao CNPq (financiamento do projeto Estudo e conservação de Orchidaceae na Amazônia Brasileira), ao Sr.Antônio Elielson Rocha (MPEG) pelas ilustraçōes e ao Dr. Gustavo A. Romero-Gonzalez pelas bibliografias cedidas.

\section{BIBLIOGRAFIA CITADA}

Barros, F. 1996. Notas taxonômicas para espécies brasileiras dos gêneros Epidendrum, Platystele, Pleurothallis e Scaphyglottis (Orchidaceae). Acta Botanica Brasilica, 10(1): 139-151.

Bechtel, H.; Cribb, P.; Saunert, E. 1986. The manual of cultivated orchid species. British Library Cataloguing in Publication Data, London. 585pp.

Brummitt, R.K.; Powell, C.E. 1992. Authors of plant names. Royal Botanic Gardens, Kew. 732pp.

Cogniaux, C.A. 1903. Plantae Hasslerianae soit Enumeration des plantes recoltees au Paraguay. Bulletin de l' herbier. Boissier, 2(3): 933.

Cogniaux, C.A. 1895. Orchidaceae. In Martius, K.F.P. von, Flora Brasiliensis, 5(3): 292-310.

Dressler, R.L. 1993. Phylogeny and classification of the orchid family. Harvard University Press, Cambridge. 314pp.

Foldats, E. 1970. Orchidaceae. In Lesser, T. Flora de Venezuela. Instituto Botanico, Caracas. 4(3): 498-514.

Garay, L.A. 1960. On the origin of the Orchidaceae II - Botanical Museum Leaflets. 19: 57-96.

Hoehne, F.C. 1952. Galeandra styllomisantha. Arquivos de Botânica do Estado de São Paulo. 2: 146.

Hoehne, F.C. 1912. Galeandra. Relatório, Commissão das Linhas Telegráficas Estratégicas de Matto Grosso ao Amazonas. Anexo 5, Bot. 4: 13-17.

Holmgren, P. K.; Holmgren; N. H.; Barnett, L. C. 1990. Index herbariorum. P. I. The herbaria of the world. $8^{\text {th }} \mathrm{Ed}$. New York: New York Botanical Garden. 693pp.

Lemaire, A.C. (1847). Phajus rosellus. Flore des Serres, Paris. 3: 301.

Lindley, J. 1832. in: Bauer, F.A. Illustrations of orchidaceous plants. Londres: J. Ridgeway and Sons. t. 8.
Lindley, J. 1840. Sertum orchidaceum: wreath of the most beautiful orchidaceous flowers. J. Ridgway \& Sons, London. sub 1: 37.

Pabst, G.F.J.; Dungs, F. 1975. Orchidaceae Brasiliensis I. BruckeVerlag Schmersow, Hildesheim, Germany. 408pp.

Pabst, G.F.J.; Dungs, F. 1977. Orchidaceae Brasiliensis II. BruckeVerlag Schmersow, Hildesheim, Germany. 418pp.

Radford, A.E.; Dickinson, W.C.; Massey, J.R.; Bell, C.R. 1974. Vascular plant systematics. Harper \& Row, New York. 891pp.

Reichenbach, H.G. L. 1841. Der deutsche botaniker das herbarienbuch. Arnoldischen

Buchhandlung, Dresden, Leipzig. 213pp.

Reicheibach, H.G. 1849. Galeandra beyrichii. Linnaea, 22: 854.

Reicheibach, H.G. 1887. Chronique Horticole. Illustration Horticole, 34, t. 22: 63.

Reicheibach, H.G.; Warming E. 1881. Novitiae Orchidaceae. Otia Botanica Hamburgensia, 2: 88.

Reicheibach, H.G. 1856. Galeandra stangeana. Bonplandia, 4: 323.

Rodrigues, J.B. 1881. Orchideae Rodeienses et alterae ineditae. Revista de Engenharia, 3(9): 143.

Rodrigues, J.B. 1881. Resultado botânico de uma breve excursão a São João d' El-Rey, Minas Gerais. Revista de Engenharia, 3(5): 73.

Rodrigues, J.B. 1877. Genera et species Orchidearum novarum I. C. \& H. Fleiuss. Sebastianópolis, Rio de Janeiro. 191pp.

Schlechter, F.R.R. 1910. Orchidaceae novae et criticae. Repertorium Specierum Novarum Regni Vegetabilis, 8: 454.

Schlechter, F.R.R. 1920. Beiträge zur kenntnis der orchidaceenflora von Parana. Repertorium Specierum Novarum Regni Vegetabilis, 16: 331 .

Schlechter, F.R.R. 1922. Galeandra fiebrigii. Repertorium Specierum Novarum Regni Vegetabilis, 10: 47.

Senghas, K. 1991. Galeandra. In Escobar, R.R (ed.), Native Colombian orchids. 2: 188-191.

Sheehan, T.J.; Sheehan M. 1994. An illustrated survey of orchid genera. Timber Press, Portland. 420pp.

Sprunger, S.; Cribb, P.; Toscano-de-Brito, A.L.V. (eds.) 1996. Iconographie des orchidées du Brèsil. vol. 1. Reinhardt, Basle. $182 \mathrm{pp}$.

Velloso, J.M.C. 1831. Flora Fluminensis. Archivos do Museu Nacional do Rio de Janeiro, 9, t. 46: 183.

Werkhoven, M.C.M. 1986. Orchids of Suriname. Vaco, Paramaribo. 256pp.

Willis, J.C. 1973. A dictionary of the flowering plants and ferns. University Press, Cambridge. 1243pp.

Recebido em 18/10/2006

Aceito em 08/01/2009 
